\title{
Front Matter: Volume 11732
}

, "Front Matter: Volume 11732," Proc. SPIE 11732, Dimensional Optical Metrology and Inspection for Practical Applications X, 1173201 (3 May 2021); doi: $10.1117 / 12.2598596$

SPIE. Event: SPIE Defense + Commercial Sensing, 2021, Online Only 


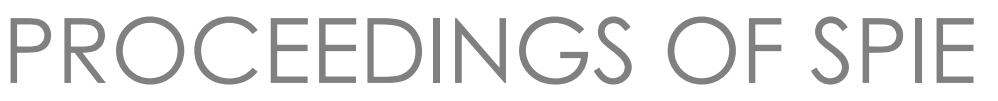

\section{Dimensional Optical Metrology and Inspection for Practical Applications $X$}

Kevin G. Harding

Song Zhang

Beiwen Li

Editors

12-16 April 2021

Online Only, United States

Sponsored and Published by

SPIE

Volume 11732 
The papers in this volume were part of the technical conference cited on the cover and title page. Papers were selected and subject to review by the editors and conference program committee. Some conference presentations may not be available for publication. Additional papers and presentation recordings may be available online in the SPIE Digital Library at SPIEDigitalLibrary.org.

The papers reflect the work and thoughts of the authors and are published herein as submitted. The publisher is not responsible for the validity of the information or for any outcomes resulting from reliance thereon.

Please use the following format to cite material from these proceedings:

Author(s), "Title of Paper," in Dimensional Optical Metrology and Inspection for Practical Applications $X$, edited by Kevin G. Harding, Song Zhang, Beiwen Li, Proc. of SPIE 11732, Seven-digit Article CID Number (DD/MM/YYYY); (DOI URL).

ISSN: 0277-786X

ISSN: 1996-756X (electronic)

ISBN: 9781510643017

ISBN: 9781510643024 (electronic)

Published by

SPIE

P.O. Box 10, Bellingham, Washington 98227-0010 USA

Telephone +1 3606763290 (Pacific Time)

SPIE.org

Copyright @ 2021 Society of Photo-Optical Instrumentation Engineers (SPIE).

Copying of material in this book for internal or personal use, or for the internal or personal use of specific clients, beyond the fair use provisions granted by the U.S. Copyright Law is authorized by SPIE subject to payment of fees. To obtain permission to use and share articles in this volume, visit Copyright Clearance Center at copyright.com. Other copying for republication, resale, advertising or promotion, or any form of systematic or multiple reproduction of any material in this book is prohibited except with permission in writing from the publisher.

Printed in the United States of America by Curran Associates, Inc., under license from SPIE.

Publication of record for individual papers is online in the SPIE Digital Library.

\section{SPIE. DIGITAL}

Paper Numbering: A unique citation identifier (CID) number is assigned to each article in the Proceedings of SPIE at the time of publication. Utilization of CIDs allows articles to be fully citable as soon as they are published online, and connects the same identifier to all online and print versions of the publication. SPIE uses a seven-digit CID article numbering system structured as follows:

- The first five digits correspond to the SPIE volume number.

- The last two digits indicate publication order within the volume using a Base 36 numbering system employing both numerals and letters. These two-number sets start with 00, 01, 02, 03, 04, 05, 06, 07, 08, 09, 0A, OB ... 0Z, followed by 10-1Z, 20-2Z, etc. The CID Number appears on each page of the manuscript. 


\section{Contents}

3D METHODS

1173203 High-resolution structured light 3D vision for fine-scale characterization to assist robotic assembly [11732-1]

1173204 Mid-wave infrared 3D sensor based on sequential thermal fringe projection for fast and accurate shape measurement of transparent objects [11732-2]

1173205 Low latency real time 3D sensor utilizing optimized aperiodic fringe patterns [11732-3]

1173206 3D scene capture using passive IR and focus diversity [1 1732-4]

1173207 Fringe pattern denoising based on robust principal component analysis [11732-5]

1173208 A data fusion approach to improving moving object measurement using phase-shifting profilometry [11732-6]

OPTICAL INSPECTION METHODS AND APPLICATIONS

1173209 Performance evaluation of line confocal imaging for surface roughness measurement application (Invited Paper) [11732-7]

11732 OA Standard-compliant detection of fillet weld surface imperfections for MAG-welding using a 3D-line scanner [11732-8]

$11732 \mathrm{OB} \quad$ A new approach for controlling of curved cutting edges of toroid-shaped end-milling cutter [11732-9]

11732 OC Detection and tracking of laser damage on LMJ vacuum windows by digital image correlation [11732-10]

\section{POSTER SESSION}

$117320 \mathrm{D} \quad$ Algorithm for the automated determination of heating areas during metal processing with numerically controlled machines [11732-11]

$11732 \mathrm{OE} \quad$ Algorithm for fusing data obtained by thermal, 3D, and the visible range cameras [1 1732-12] 
Proc. of SPIE Vol. 11732 1173201-4

\section{Downloaded From: https://www.spiedigitallibrary.org/conference-proceedings-of-spie on 26 Apr 2023
Terms of Use: https://www.spiedigitallibrary.org/terms-of-use}

